Review Article

\title{
Premenarche bilateral giant juvenile fibroadenoma of breast: literature review with a case report
}

\author{
Mezhuneituo Raleng ${ }^{1 *}$, Samir Anand ${ }^{2}$, Shailesh Kannurgh ${ }^{3}$
}

\author{
${ }^{1}$ Department of Surgical Oncology, Health City Hospital, Assam, India \\ ${ }^{2}$ Department of Surgery, M M Medical College and Hospital, Himachal Pradesh, India \\ ${ }^{3}$ Department of Surgery, BLDE Shri B M Patil Hospital, Karnataka, India
}

Received: 08 November 2021

Accepted: 02 December 2021

\author{
*Correspondence: \\ Dr. Mezhuneituo Raleng, \\ E-mail: neituo@gmailcom
}

Copyright: ( ) the author(s), publisher and licensee Medip Academy. This is an open-access article distributed under the terms of the Creative Commons Attribution Non-Commercial License, which permits unrestricted non-commercial use, distribution, and reproduction in any medium, provided the original work is properly cited.

\begin{abstract}
Fibroadenoma is a common abnormality which every surgeon has been exposed to, and there are several international guidelines regarding its management. However giant fibroadenomas, especially in the premenarche setting has been a rare occurrence, even for the experienced surgeon. Various reports have shown that we need to treat this condition more aggressively than the normal fibroadenoma, and issues of cosmesis in a developing breast along with the aim to preserve lactation functionality becomes an issue. Since these cases remain a single life time experience for most surgeons, there is a sparsity of treatment protocols even in literature. Through this paper we hope to shed some valuable insight to this rare disorder and help surgeon colleagues, when dealing with similar cases.
\end{abstract}

Keywords: Fibroadenoma, Giant, Premenarche, Bilateral, Breast

\section{INTRODUCTION}

Fibroadenomas are the commonest breast lumps encountered in young women accounting for $70 \%$ to $95 \%$ of breast biopsies, Neinstein et al reported fibroadenoma involving $68.3 \%$ of breast lumps in women less than 22 years, autopsies have shown an incidence of 15 to $23 \%$ and epidemiologic studies an incidence of $2.2 \% .^{1-4}$ Giant fibroadenoma are rare, constituting about $4 \%$ and a further subtype the giant juvenile fibroadenoma constitutes only $0.5 \% .^{5}$ There are only a handful reports of bilateral giant juvenile fibroadenoma in adolescent females and it is more uncommon in premenarche girls. ${ }^{6-}$ 17 Our review focuses on premenarche bilateral giant fibroadenomas; presently due to its rarity there is no data about its population incidence, prevalence and management protocols.

Clinical scenarios have proved that this entity is more complex than previously imagined and a multi departmental team is required for most cases.

\section{METHODS}

We did a Pubmed and Medline search in January 2020 with the search words 'fibroadenoma' 'giant' 'juvenile' 'bilateral' and got 12 articles. Inclusion criteria included: case reports or case series of bilateral giant juvenile fibroadenoma in premenarch girls. Articles were excluded in unilateral cases, postmenarche girls and articles which did not specify about the menarche. After screening 5 articles met our criteria, abstract to full text review of relevant articles was done and bibliography of relevant articles were reviewed for missed articles.

\section{Case report}

A 14 year premenarche girl presented with a rapidly increasing right breast lump which she noticed three months back. On presentation she had two lump of $10 \times 7 \mathrm{~cm}$ and $4 \times 1.7 \mathrm{~cm}$ on her right breast, the lumps were mobile, skin was not involved, nipple areolar complex was normal and there was no axillary lumps. Fine needle 
aspiration cytology (FNAC) was consistent with a fibroadenoma. Ultrasound of bilateral breast and axilla was done but no other lumps were detected. All other routine investigations were normal and she had no known comorbid condition or familial syndrome. On surgery very little normal breast tissue was identified and the histopathological examination (HPE) was consistent with a giant fibroadenoma.

At 3 months follow up she presented with a similar lump over her left breast. Examinations and FNAC were consistent with a giant juvenile fibroadenoma. Excision biopsy was done and 3 lumps were removed largest, of which was a $6 \times 6 \mathrm{~cm}$ lump (Figure 1). Wound healed without any complications and on follow up at 3 months she informed us that her periods have started.

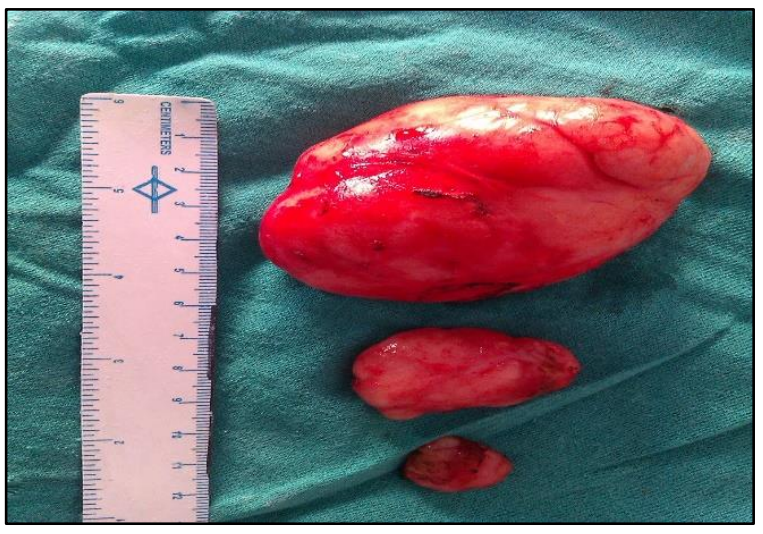

Figure 1: Three excised fibroadenoma specimen, largest $6 \mathrm{~cm}$.

\section{RESULTS}

Six cases were analysed: five publications plus our case report. All articles were from 2007 to 2017, five reports were from the Indian sub-continent and one from America. ${ }^{13-17}$ Age at presentation ranged between 9 to 14 years and predominant presenting complaint was lump with pain.

Duration of lump was between 2 to 12 months with an average of 5.6 months. Two patients had skin ulceration on presentation, in one patient both the nipple areola complex were destroyed. ${ }^{16,17}$ There were no known comorbidities/syndromes, no medical therapy was attempted before the surgery and no reconstruction was done. Majority of the reports had single giant fibroadenoma and some multiple fibroadenoma on one breast, only our patient had multiple bilateral fibroadenoma. The largest fibroadenoma was $22 \mathrm{~cm}$ in size and smallest $6 \mathrm{~cm}$, with an average size of $12.7 \mathrm{~cm}$ on the right breast and $13.3 \mathrm{~cm}$ on the left breast. Heaviest fibroadenoma recorded was 950 gms. ${ }^{15}$ There was no recurrence till the time the case reports were published and no long term results of any of the reports are available. Patient characteristics are summarised in Table 1.

\section{DISCUSSION}

Fibroadenoma is a byproduct of lobular hyperplasia from a single lobule containing epithelial and stromal component.3 Definition of giant fibroadenoma has generally been considered as $>5 \mathrm{~cm}$, while some authors defines it as $>500 \mathrm{~g}$, or when replacing at least four-fifths of the breast tissue. $3,18,19$

In our review five out of the six reports are from the Indian subcontinent, but generally it has been considered that fibroadenomas are more common in the African population, this may simply be due to under reporting from the African nations or may be an actual occurrence..$^{20,21}$ The picture will become clearer if more reports are published.

Table 1: Baseline patient characteristics.

\begin{tabular}{|c|c|c|c|c|c|c|c|c|}
\hline \multirow{2}{*}{ Author } & \multirow{2}{*}{ Country } & \multirow{2}{*}{$\begin{array}{l}\text { Age } \\
(\mathbf{Y})\end{array}$} & \multirow{2}{*}{$\begin{array}{l}\text { Duration } \\
\text { (months) }\end{array}$} & \multicolumn{2}{|c|}{$\begin{array}{l}\text { Focality } \\
\text { Single/Multiple }\end{array}$} & \multicolumn{2}{|c|}{ Size in $\mathrm{cm}$} & \multirow{2}{*}{ Surgery } \\
\hline & & & & $\begin{array}{l}\text { Right } \\
\text { breast }\end{array}$ & $\begin{array}{l}\text { Left } \\
\text { breast }\end{array}$ & $\begin{array}{l}\text { Right } \\
\text { breast }\end{array}$ & $\begin{array}{l}\text { Left } \\
\text { breast }\end{array}$ & \\
\hline Moore $2007^{17}$ & USA & 9 & 12 & Single & Single & $17 X 15$ & $18.5 \times 16$ & $\begin{array}{l}\mathrm{b} / 1 \text { subtotal } \\
\text { mastectomy }\end{array}$ \\
\hline $\begin{array}{l}\text { Mukhopadhyay } \\
2009^{16}\end{array}$ & India & 11 & 2 & Single & Single & $22 X 20$ & $18 X 16$ & Excision \\
\hline Nikumbh $2011^{15}$ & India & 12 & 3 & Single & Single & $\begin{array}{l}\text { 15X12 } \\
(800 \\
\mathrm{gms})\end{array}$ & $\begin{array}{l}17 X 15 \\
(950 \\
\text { gms })\end{array}$ & Excision \\
\hline Khan $2015^{14}$ & Pakistan & 10 & 12 & Single & Single & $\begin{array}{l}6 X 5 \\
(509 \\
\text { gms })\end{array}$ & $\begin{array}{l}\text { 10X15 } \\
(754 \\
\text { gms) }\end{array}$ & Excision \\
\hline Makkar $2017^{13}$ & India & 14 & 2 & Single & Multiple & $6 \times 5$ & $10 \times 6$ & Excision \\
\hline Raleng 2021 & India & 14 & 3 & Multiple & Multiple & $10 \times 7$ & $6 \times 6$ & Excision \\
\hline
\end{tabular}


Premenopausal bilateral giant juvenile fibroadenoma gives rise to some unique problems:

Patients with unilateral giant fibroadenoma can offer lactation later in life, but in bilateral giant fibroadenomas, if bilateral mastectomy were performed lactation is not possible. $^{6,8,12,17,22}$ The sparsity of breast tissue might confuse surgeons regarding the extent of surgery, especially when there is suspicion for a phyllodes tumour. Since this concerns young women; though no studies have been done; cosmetic issues are of prime importance.

\section{Hormonal perspective}

It is known that breast development (thelarch) occurs about 2 years earlier than onset of periods in females (menarch), and the primary hormones responsible for breast development are estradiol; which influences ductal development; and progesterone stimulates lobular development. ${ }^{18,23,24}$ Sapino et al studied specimens of fibroadenoma and phyllodes tumor, and found increased expression of estrogen receptor $\beta$, suggesting estrogen in the pathogenesis of these tumours. Later Branchini et al found increased levels of progesterone receptors A and B in women with fibroadenomas, indication that progesterone and not estrogen receptors might be responsible. $^{25,26}$

Welsch et al in 1979 suggested that prolactin levels might be related to fibroadenoma stimulation, since than Nicol et al have showed high prolactin levels in a minor population of benign and malignant breast patients. ${ }^{27,28}$ Recent reports have suggested that it may be the increase expression of prolactin receptors in fibroadenomas and perhaps not the prolactin levels by itself. ${ }^{29,30}$ Steroid receptors may also plays a role, owing to reports of fibroadenoma increasing in size during pregnancy and lactation, and its regression after menopause. ${ }^{19}$

\section{Malignant transformation concerns}

Dupont et al did a long term follow up in 1,835 patients and concluded that relative risk of invasive cancer is higher by 2.17 in patients with fibroadenomas. ${ }^{31}$ Other smaller series found malignant transformation of about $0.3 \% .{ }^{32}$ Contrary to the above studies, Neisntein et al after a longitudinal study in adolescent patients concluded prevalence of malignancies in fibroadenomas as practically $0 \% .^{2}$ Carter after following up the same cohort of patients as Dupont stated that there is no long term risk for malignancy in women with fibroadenomas containing atypias. ${ }^{31,33}$ Other reports have also confirmed that malignant transformation in fibroadenomas is not of significant clinical concern and remains a rare occurrence. ${ }^{34,35}$ Irrespective of what the literature says, for patients the fear of malignancy is one of their primary distress and this should be discussed in detailed with them. None of our reports have long term follow up results; we are yet to understand how it behaves in a giant fibroadenoma.

\section{Diagnosis}

Greatest diagnostic dilemma for a giant fibroadenoma is differentiating with phyllodes tumour, they have similar parameters on clinical, imaging, and histopathological examination. Phyllodes tumour occurs in 0.3 to $1 \%$ of breast tumors and though very rare in children, phyllodes tumour should always be considered as a differential diagnosis when dealing with a giant fibroadenoma. ${ }^{36,37}$ While fibroadenoma just needs simple excision, phyllodes tumour needs a more radical approach with a minimum of $1 \mathrm{~cm}$ wide excision, and addition of adjuvant therapies..$^{38,39}$

Ultrasound currently is the preferred method of investigation in young girls for a breast lumps. In a series of 115 pediatric patients Omar et al could accurately detect almost $98 \%$ of fibroadenomas with ultrasound, 3 patients which were missed had phyllodes tumour; all diagnosis were confirmed with excision and histopathological examination. ${ }^{40}$ Duman et al also suggested that ultrasound, mammogram and MRI could help differentiate between fibroadenoma and phyllodes tumour for tumours $>3 \mathrm{~cm}$, but Yilmaz et al reported that we cannot differentiate fibroadenoma from phyllodes tumour depending on their mammographic and ultrasound features, due to numerous overlap in image characteristics. $^{41,42}$

Core needle biopsy (CNB) is the established investigation for breast lumps suspicious for malignancies, because of its added benefits in evaluating the estrogen/progesterone receptor and Her-2 status. ${ }^{43,44}$ In a landmark article Lawton et al showed that even experience pathologist who specialise in breast pathology struggle to distinguish between some cellular fibroadenoma and phyllodes tumour. ${ }^{45}$ For fibroadenomas Smith et al showed that CNB did not add benefit in ladies less than 25 years, and FNAC should be the preferred choice. ${ }^{46}$ However, Bode et al evaluated 54 patients, with their excision biopsy results and concluded that $\mathrm{CNB}$ was able to differentiate between fibroadenoma and phyllodes tumour with some certainty; with false negative rate (FNR) of $17 \%$ for phyllodes tumour. ${ }^{47}$ Although FNR for fibroadenoma was $40 \%$ in that study, this was due to $33 \%$ showing other benign pathology. Gatta et al in a larger series confirmed that $\mathrm{CNB}$ had the highest sensitivity, specificity and positive predictive values $(81 \%, 97 \%$ and $87 \%$ $(\mathrm{p}=0.001))$ compared to mammography and ultrasound, in differentiating fibroadenoma from phyllodes tumour. ${ }^{48}$ The WHO 2012 criteria for phyllodes tumour was explored by Chang et al, they found an increased diagnosis of benign phyllodes and a decrease in fibroadenoma after its use. ${ }^{49}$

Adamietz et al examined 123 lesions of fibroadenoma and 8 phyllodes tumour with real time elastography, they 
found that all phyllodes tumour had similar elastic pattern referred to as the "ring sign"; this was found in only 5\% of fibroadenoma. ${ }^{50}$ In 2014 a larger retrospective data of 350 breast lesions were analyzed, they found a mean strain ratio of $3.19 \pm 2.33,2.94 \pm 2.35$ and $1.69 \pm 0.88$ for malignant phyllodes, borderline phyllodes and fibroadenoma, suggesting that elastograph could help differentiate between fibroadenoma and phyllodes tumour. ${ }^{51}$

From these evidences in literature, we can conclude that, a multimodality imaging and core biopsy gives the best results, to differentiate between giant fibroadenomas and phyllode tumors.

\section{Genetics}

Koutselini et al first studied p53 in breast cells; 38 out of $39(97.4 \%)$ benign breast tumors stained negative for p53. ${ }^{52}$ Franco et al in 2001 reported absence of TP53 mutations in fibroadenomas. ${ }^{53}$ Later Hodges et al in 2009 after analysing a case of synchronous fibroadenoma and phyllodes tumour, reported allelic loss at TP53 and D22S264, while Schneider et al found increased p53 gene in fibroadenoma specimens. ${ }^{54,55}$ The exact role of p53 in fibroadenomas is not well understood.

Cancer syndromes like Mafucci's, Cowden's syndrome and Carney complex are associated with multiple fibroadenomas, however no association with premenarch bilateral juvenile giant fibroadenomas have been proven yet. $^{19}$

\section{Treatment}

Presently there is no consensus in the treatment of giant juvenile fibroadenomas, complete excision while preserving the developing breast and the nipple areola complex is the goal. ${ }^{56}$ Mastectomy in certain cases with or without reconstruction may be required; delayed reconstruction might be a better choice due to the recurrent nature of this disease. ${ }^{6,17}$ Since spontaneous regression is known to occur in $1 \%$ to $19 \%$ of FA, for lumps $<5 \mathrm{~cm}$ watchful observation every 2-6 months for up to 2 years, is the protocol followed by many centers. ${ }^{2,57}$ Observation does not entail a casual approach, some bilateral giant fibroadenoma seems to have the capacity to grow rapidly; some patients in this series had massive growth within 2-3 months. ${ }^{13,15,16}$ If not treated in time they can give rise to challenging local complications, including nipple areola complex destruction or ulcerated growth mimicking breast cancer. $^{17,22}$

\section{Tamoxifen}

Since estrogen is postulated in the development of fibroadenomas, tamoxifen a selective estrogen receptor modulator became the natural choice in its treatment. Chiu et al examined 13,203 patients from NSABP Breast
Cancer Prevention Trial and reported that tamoxifen reduces the risk for fibroadenomas $(\mathrm{RR}=0.77$, 95\% $\mathrm{CI}=0.56$ to 1.04$).{ }^{58,59}$ Viviani et al did a randomised controlled trial and found that $20 \mathrm{mg}$ tamoxifen/day for 50 days caused a reduction in fibroadenomas. ${ }^{60} \mathrm{In}$ another randomised controlled trial, in premenopausal women and found that proliferative cell nuclear antigen, a marker of cell proliferation was reduced with $20 \mathrm{mg}$ tamoxifen $(\mathrm{p}=0.031)$; however this study is criticized for a wide confidence interval (1.39-26.67) ${ }^{61}$ MIB-1 has also shown co-relation with tumor size, nodal metastasis, p53 overexpression, and an independent predictor of overall survival (RR 2.92, 95\% CI 1.05-8.01, p<0.05), and disease free survival (RR 2.01, 95 CI 1.05-3.83, p<0.05) in breast cancers. ${ }^{62-64}$ In the randomized controlled trial done by De Sousa et al65 on fibroadenomas, there was significant reduction in MIB-1 with 10/20 mg tamoxifen, and reduction in PRL levels with $20 \mathrm{mg}$ tamoxifen $(\mathrm{p}=0.005)$.

Several studies from India has shown that centchroman (ormeloxifene) a nonsteroidal antiestrogen drug can promote complete regression in 31 to $40 \%$ fibroadenomas, but its role in giant juvenile fibroadenomas not clear so far. ${ }^{57,66}$

\section{Novel techniques}

Kitamura introduced the technique of endoscopy-assisted breast surgery (EABS) for benign breast tumors in $1998 .{ }^{67}$ In 2016 the Taiwan Endoscopic Breast Surgery Cooperative Group reported their experience, a total of 315 EABS procedures for breast cancers were performed between 2009 and 2014, with positive surgical margin rate of $1.9 \%{ }^{68}$ In 2017, Lai et al reported EABS in benign breast tumors, 323 EABS procedures were performed, the mean tumor size was $2.2 \mathrm{~cm}$, with overall minor complications rate of $6.5 \%$. Out of 110 patients $85.4 \%$ reported being satisfied with the cosmetic result. ${ }^{69}$ The only endoscopic publication for giant fibroadenomas are by Cheng et al, they published a 3 case report, the fibroadenomas ranged from 5 to $10 \mathrm{~cm}$ all were extracted with the help of an endoscope through a 1.5 to $4 \mathrm{~cm}$ preiareolar incision. ${ }^{70}$ The above reports suggest that EABS/robotic surgery is a possibility for selected giant fibroadenomas and they will provide the advantage of good cosmesis which is an added advantage for young girls.

Angio embolisation to shrink the tumour, has also been tried for huge bilateral giant juvenile fibroadenomas, more reports will be needed before we can validate its use routinely. ${ }^{7}$

\section{CONCLUSION}

Premenarche bilateral giant juvenile fibroadenomas needs to be treated speedily and aggressively, diagnosis whenever applicable should be with $\mathrm{CNB}$ and multimodal imaging. Wide excision should be the 
primary form of treatment, delayed reconstruction in consultation with plastic surgeons is a sensible choice. Tamoxifen if contemplated should be initiated early, for best results. Patient and parents needs proper counselling regarding body image issues and expectation of cosmetic surgery.

Funding: No funding sources

Conflict of interest: None declared

Ethical approval: Not required

\section{REFERENCES}

1. Greydanus DE, Matytsina-Quinlan L. Breast concerns and disorders in adolescent females. Pediatric Medicine. 2019;2(0).

2. Neinstein LS. Breast disease in adolescents and young women. Pediatr Clin North Am. 1999;46(3):607-29.

3. Goehring C, Morabia A. Epidemiology of benign breast disease, with special attention to histologic types. Epidemiol Rev. 1997;19(2):310-27.

4. Santen RJ, Mansel R. Benign breast disorders. N Engl J Med. 2005;353(3):275-85.

5. Dent DM, Cant PJ. Fibroadenoma. World J Surg. 1989;13(6):706-10.

6. Laitano FF, Neto FL, Zerwes FP. Bilateral giant juvenile fibroadenomas of the breasts-a rare indication for bilateral skin reducing mastectomy. Gland Surg. 2016;5(4):435-8.

7. Rafeek N, Rangasami R, Dhanraj K, Joseph S. Multimodality approach in the diagnosis and management of bilateral giant juvenile breast fibroadenoma. BMJ Case Rep. 2016;2016.

8. Kaur N, Saini S, Somasekhar S, Gupta A. Bilateral Florid Juvenile Fibroadenomas of the Breast in an Adolescent: A Rare Indication for Subcutaneous Mastectomy. J Pediatr Adolesc Gynecol. 2015;28(5):e135-7.

9. Morris A, Shaffer K. Recurrent Bilateral Giant Fibroadenomas of the Breasts. Radiology Case Reports. 2007;2(3):96.

10. Lee CJ, Kim YJ, Seo YT, Pak SJ, Lee SI. Treatment of multiple bilateral juvenile fibroadenomas in a teenage breast by central pedicle breast reduction, with vertical and short horizontal scar: case report. Aesthetic Plast Surg. 2004;28(4):228-30.

11. Baxi M, Agarwal A, Mishra A, Agarwal G, Mishra SK. Multiple bilateral giant juvenile fibroadenomas of breast. Eur J Surg. 2000;166(10):828-30.

12. Silfen R, Skoll PJ, Hudson DA. Florid juvenile (cellular) fibroadenomatosis in the adolescent: a case for subcutaneous mastectomy? Aesthetic Plast Surg. 1999;23(6):413-5.

13. Makkar N, Singh S, Paul S, Sandhu MS, Kumar A. Bilateral Giant Juvenile Fibroadenoma of Breast. J Clin Diagn Res. 2017;11(6):ED10-2.

14. Khan S, Khan M, Rafique S. Giant Bilateral Juvenile Fibroadenoma of the Breast in
Prepubescent Girl. J Coll Physicians Surg Pak. 2015;25:S95-96.

15. Nikumbh DB, Desai SR, Madan PS, Patil NJ, Wader JV. Bilateral giant juvenile fibroadenomas of breasts:a case report. Patholog Res Int. 2011;2011:482046.

16. Mukhopadhyay M, Patra R, Mondal S, Ghosh A, Ray AK. Bilateral giant juvenile fibroadenoma of breasts. J Indian Assoc Pediatr Surg. 2009;14(2):68-9.

17. 1Moore RL, Mungara A, Shayan K, Wallace AM. Bilaterally symmetric juvenile fibroadenomas and tubular breast deformity in a prepubescent girl. Journal of Pediatric Surgery. 2007;42(6):1133-6.

18. Arca MJ, Caniano DA. Breast disorders in the adolescent patient. Adolesc Med Clin. 2004;15(3):473-85.

19. Jayasinghe Y, Simmons PS. Fibroadenomas in adolescence. Current Opinion in Obstetrics and Gynecology. 2009;21(5):402.

20. Oluwole SF, Freeman HP. Analysis of benign breast lesions in blacks. Am J Surg. 1979;137(6):786-9.

21. Funderburk WW, Rosero E, Leffall LD. Breast lesions in blacks. Surg Gynecol Obstet. 1972;135(1):58-60.

22. Arowolo OA, Akinkuolie AA, Adisa AO, Obonna GC, Olasode BJ. Giant fibroadenoma presenting like fungating breast cancer in a Nigerian teenager. African Health Sciences. 2013;13(1):162-165-5.

23. Marshall WA, Tanner JM. Variations in pattern of pubertal changes in girls. Arch Dis Child. 1969;44(235):291-303.

24. Cabrera SM, Bright GM, Frane JW, Blethen SL, Lee PA. Age of thelarche and menarche in contemporary US females: a cross-sectional analysis. J Pediatr Endocrinol Metab. 2014;27(0):47-51.

25. Sapino A, Bosco M, Cassoni P, Castellano I, Arisio $\mathrm{R}$, Cserni G, et al. Estrogen receptor- $\beta$ is expressed in stromal cells of fibroadenoma and phyllodes tumors of the breast. Mod Pathol. 2006;19(4):599-606.

26. Branchini G, Schneider L, Cericatto R, Capp E, Brum IS. Progesterone receptors A and B and estrogen receptor alpha expression in normal breast tissue and fibroadenomas. Endocrine. 2009;35(3):459-66.

27. Welsch CW, Dombroske SE, McManus MJ, Calaf G. Effect of human, bovine and ovine prolactin on DNA synthesis by organ cultures of benign human breast tumours. Br J Cancer. 1979;40(6):866-71.

28. Nicol M, Willis C, Yiangou C, Sinnett D, Shousha S. Relationship Between Serum Prolactin Levels and Histology of Benign and Malignant Breast Lesions: A Detailed Study of 153 Consecutive Cases. The Breast Journal. 2002;8(5):281-5.

29. Gill S, Peston D, Vonderhaar BK, Shousha S. Expression of prolactin receptors in normal, benign, and malignant breast tissue: an immunohistological study. J Clin Pathol. 2001;54(12):956-60. 
30. Touraine P, Martini JF, Zafrani B, Durand JC, Labaille F, Malet C, et al. Increased expression of prolactin receptor gene assessed by quantitative polymerase chain reaction in human breast tumors versus normal breast tissues. J Clin Endocrinol Metab. 1998;83(2):667-74.

31. Dupont WD, Page DL, Parl FF, Vnencak-Jones CL, Plummer WD, Rados MS, et al. Long-term risk of breast cancer in women with fibroadenoma. N Engl J Med. 1994;331(1):10-5.

32. Ozzello L, Gump FE. The management of patients with carcinomas in fibroadenomatous tumors of the breast. Surg Gynecol Obstet. 1985;160(2):99-104.

33. Carter BA, Page DL, Schuyler P, Parl FF, Simpson JF, Jensen RA, et al. No elevation in long-term breast carcinoma risk for women with fibroadenomas that contain atypical hyperplasia. Cancer. 2001;92(1):30-6.

34. Shaik AN, Ruterbusch JJ, Abdulfatah E, Shrestha R, Daaboul MHDF, Pardeshi V, et al. Breast fibroadenomas are not associated with increased breast cancer risk in an African American contemporary cohort of women with benign breast disease. Breast Cancer Res. 2018;20(1):91.

35. Diaz NM, Palmer JO, McDivitt RW. Carcinoma arising within fibroadenomas of the breast. A clinicopathologic study of 105 patients. Am J Clin Pathol. 1991;95(5):614-22.

36. Barrio AV, Clark BD, Goldberg JI, Hoque LW, Bernik SF, Flynn LW, et al. Clinicopathologic features and long-term outcomes of 293 phyllodes tumors of the breast. Ann Surg Oncol. 2007;14(10):2961-70.

37. Leraas HJ, Rosenberger LH, Ren Y, Ezekian B, Nag UP, Reed CR, et al. Pediatric phyllodes tumors: A review of the National Cancer Data Base and adherence to NCCN guidelines for phyllodes tumor treatment. J Pediatr Surg. 2018;53(6):1123-8.

38. Guillot E, Couturaud B, Reyal F, Curnier A, Ravinet J, Laé M, et al. Management of phyllodes breast tumors. Breast J. 2011;17(2):129-37.

39. Adesoye T, Neuman HB, Wilke LG, Schumacher JR, Steiman J, Greenberg CC. Current Trends in the Management of Phyllodes Tumors of the Breast. Ann Surg Oncol. 2016;23(10):3199-205.

40. Omar L, Gleason MK, Pfeifer CM, Sharma P, Kwon JK. Management of Palpable Pediatric Breast Masses With Ultrasound Characteristics of Fibroadenoma: A More Conservative Approach. American Journal of Roentgenology. 2018;212(2):450-5.

41. Duman L, Gezer NS, Balcı P, Altay C, Başara I, Durak MG, et al. Differentiation between Phyllodes Tumors and Fibroadenomas Based on Mammographic Sonographic and MRI Features. Breast Care (Basel). 2016;11(2):123-7.

42. Yilmaz E, Sal S, Lebe B. Differentiation of phyllodes tumors versus fibroadenomas. Acta Radiologica. 2002;43(1):34-9.
43. Wang M, He X, Chang Y, Sun G, Thabane L. A sensitivity and specificity comparison of fine needle aspiration cytology and core needle biopsy in evaluation of suspicious breast lesions: A systematic review and meta-analysis. Breast. 2017;31:157-66.

44. Willems SM, Deurzen CHM van, Diest PJ van. Diagnosis of breast lesions: fine-needle aspiration cytology or core needle biopsy? A review. Journal of Clinical Pathology. 2012;65(4):287-92.

45. Lawton TJ, Acs G, Argani P, Farshid G, Gilcrease $\mathrm{M}$, Goldstein $\mathrm{N}$, et al. Interobserver variability by pathologists in the distinction between cellular fibroadenomas and phyllodes tumors. Int J Surg Pathol. 2014;22(8):695-8.

46. Smith GEC, Burrows P. Ultrasound diagnosis of fibroadenoma - is biopsy always necessary? Clin Radiol. 2008;63(5):511-5.

47. Bode MK, Rissanen $\mathrm{T}$, Apaja-Sarkkinen $\mathrm{M}$. Ultrasonography and core needle biopsy in the differential diagnosis of fibroadenoma and tumor phyllodes. Acta Radiol. 2007;48(7):708-13.

48. Gatta G, Iaselli F, Parlato V, Di Grezia G, Grassi R, Rotondo A. Differential diagnosis between fibroadenoma, giant fibroadenoma and phyllodes tumour: sonographic features and core needle biopsy. Radiol Med. 2011;116(6):905-18.

49. Chang J, Denham L, Dong EK, Malek K, Lum SS. Trends in the Diagnosis of Phyllodes Tumors and Fibroadenomas Before and After Release of WHO Classification Standards. Ann Surg Oncol. 2018;25(10):3088-95.

50. Adamietz BR, Kahmann L, Fasching PA, SchulzWendtland R, Uder M, Beckmann MW, et al. Differentiation between phyllodes tumor and fibroadenoma using real-time elastography. Ultraschall Med. 2011;32:E75-9.

51. Li L-J, Zeng H, Ou B, Luo BM, Xiao XY, Zhong WJ, et al. Ultrasonic Elastography Features of Phyllodes Tumors of the Breast: A Clinical Research. PLoS One. 2014;9(1).

52. Koutselini H, Malliri A, Field JK, Spandidos DA. p53 expression in cytologic specimens from benign and malignant breast lesions. Anticancer Res. 1991;11(4):1415-9.

53. Franco N, Picard SF, Mege F, Arnould L, LizardNacol S. Absence of genetic abnormalities in fibroadenomas of the breast determined at p53 gene mutations and microsatellite alterations. Cancer Res. 2001;61(21):7955-8.

54. Hodges KB, Abdul-Karim FW, Wang M, LopezBeltran A, Montironi R, Easley S, et al. Evidence for transformation of fibroadenoma of the breast to malignant phyllodes tumor. Appl Immunohistochem Mol Morphol. 2009;17(4):345-50.

55. Schneider L, Branchini G, Cericatto R, Capp E, Brum IS. Gene and protein expression of p53 and p21 in fibroadenomas and adjacent normal mammary tissue. Endocrine. 2009;35(1):118-22.

56. Sosin M, Pulcrano M, Feldman ED, Patel KM, Nahabedian MY, Weissler JM, et al. Giant juvenile 
fibroadenoma: a systematic review with diagnostic and treatment recommendations. Gland Surg. 2015;4(4):312-21.

57. Tejwani PL, Nerkar H, Dhar A, Kataria K, Hari S, Thulkar S, et al. Regression of Fibroadenomas with Centchroman: a Randomized Controlled Trial. Indian J Surg. 2015;77(2):484-9.

58. Fisher B, Costantino JP, Wickerham DL, Redmond CK, Kavanah M, Cronin WM, et al. Tamoxifen for prevention of breast cancer: report of the National Surgical Adjuvant Breast and Bowel Project P-1 Study. J Natl Cancer Inst. 1998;90(18):1371-88.

59. Tan-Chiu E, Wang J, Costantino JP, Paik S, Butch C, Wickerham DL, et al. Effects of Tamoxifen on Benign Breast Disease in Women at High Risk for Breast Cancer. J Natl Cancer Inst. 2003;95(4):302-7.

60. Viviani RSDO, Gebrim LH, Baracat EC, De Lima GR. Evaluation of the ultrasonographic volume of breast fibroadenomas in women treated with tamoxifen. Minerva Ginecol. 2002;54(6):531-5.

61. Bernardes JRM, Seixas MT, Lima GR, Marinho LC, Gebrim LH. The effect of tamoxifen on PCNA expression in fibroadenomas. Breast J. 2003;9(4):302-6.

62. Querzoli P, Albonico G, Ferretti S, Rinaldi R, Magri $\mathrm{E}$, Indelli $\mathrm{M}$, et al. MIB-1 proliferative activity in invasive breast cancer measured by image analysis. J Clin Pathol. 1996;49(11):926-30.

63. Marrelli D, Pinto E, Neri A, Megha T, Gioffrè W, Cioppa $\mathrm{T}$, et al. Mib-1 proliferation index is an independent predictor of lymph node metastasis in invasive breast cancer: a prospective study on 675 patients. Oncol Rep. 2006;15(2):425-9.

64. Neri A, Marrelli D, Pedrazzani C, Caruso S, De Stefano A, Mariani F, et al. Prognostic relevance of proliferative activity evaluated by Mib-1 immunostaining in node negative breast cancer. Eur J Surg Oncol. 2008;34(12):1299-303.

65. Sousa JAD, Seixas MTD, Lima GRD, Baracat EC, Gebrim LH. Evaluation of Monoclonal Antibody MIB-1 in the Mammary Epithelium Adjacent to Fibroadenomas in Premenopausal Women Treated with Tamoxifen. The Breast Journal. 2001;7(6):392-7.

66. Dhar A, Srivastava A. Role of centchroman in regression of mastalgia and fibroadenoma. World $\mathbf{J}$ Surg. 2007;31(6):1178-84.

67. Kitamura K, Hashizume M, Sugimachi K, Kataoka A, Ohno S, Kuwano H, et al. Early experience of endoscopic extirpation of benign breast tumors via an extra-mammary incision. Am J Surg. 1998;176(3):235-8.

68. Lai H-W, Chen S-T, Chen D-R, Chen S-L, Chang T-W, Kuo S-J, et al. Current Trends in and Indications for Endoscopy-Assisted Breast Surgery for Breast Cancer: Results from a Six-Year Study Conducted by the Taiwan Endoscopic Breast Surgery Cooperative Group. PLoS One. 2016;11(3).

69. Lai HW, Lin HY, Chen SL, Chen ST, Chen DR, Kuo SJ. Endoscopy-assisted surgery for the management of benign breast tumors: technique, learning curve, and patient-reported outcome from preliminary 323 procedures. World J Surg Oncol. 2017;15.

70. Cheng PJ, Vu LT, Cass DL, Hicks MJ, Brandt ML, Kim ES. Endoscopic specimen pouch technique for removal of giant fibroadenomas of the breast. J Pediatr Surg. 2012;47(4):803-7.

Cite this article as: Raleng M, Anand S, Kannurgh $\mathrm{S}$. Premenarche bilateral giant juvenile fibroadenoma of breast: literature review with a case report. Int Surg J 2022;9:262-8. 